\title{
Military Maladaptation: Counterinsurgency and the Politics of Failure
}

\author{
Dr. Kristen A. Harkness \\ School of International Relations \\ University of St. Andrews \\ Dr. Michael Allen Hunzeker \\ Woodrow Wilson School \\ Princeton University \\ Open Access Copy—Please Do Not Cite \\ Published in Journal of Strategic Studies 38(6): 777-800
}

"The political object is the goal, war is the means of reaching it, and means can never be considered in isolation from their purpose." -Clausewitz, On $\mathrm{War}^{1}$

Learning is critical to battlefield success. Local conditions vary broadly, even within a single theater of operations, and enemy tactics shift across both time and space. Victory becomes more likely and casualties are reduced when military organizations can adapt tactics, techniques, and procedures to changing circumstances. Modern militaries therefore continually search for better ways to learn.

The emerging literature on military adaptation has shifted focus from traditional analyses of military innovation - major doctrinal shifts and technological revolutions - to the study of incremental learning and small-scale change. Within this literature, Theo Farrell has developed the first theoretical model of military adaption, based on four key preconditions that interact to

\footnotetext{
${ }^{1}$ C. Clausewitz, On War, edited and translated by Michael Howard and Peter Paret (New York: Everyman's Library
} 1976): Book 1, Chapter 1, 87). 
collectively maximize the likelihood of successful adaption: namely, prospective defeat, poor organizational memory, decentralization, and leadership turnover. Farrell, however, develops and evaluates this model within the single case study context of the contemporary British counterinsurgency effort in Helmand Province, Afghanistan. ${ }^{2}$ Without comparative analysis and theory testing across contexts, we are left uncertain as to the generalizability and scope conditions of the model.

In this article, we evaluate Farrell's model, complemented with additional insights from the broader organizational change and military innovation literatures, against new archival material from the British counterinsurgency campaign in the Southern Cameroons (1960-61). We argue that this small-scale war is a most-likely case for adaptation given existing theory: the British army has a strong reputation as a 'learning institution' and has been praised for the effectiveness of its counterinsurgency efforts in the twilight years of empire. The British forces in the Southern Cameroons, moreover, possessed all of Farrell's preconditions. Explanatory failure in such a most-likely case would call into question existing explanations, highlight important scope conditions, and provide fertile ground for generating new theoretical insights.

We find that, in the Southern Cameroons, although the British military did successfully detect their operational shortcomings, they nevertheless failed to adapt to changing enemy tactics. By 1961, the insurgents had gained control over significant tracts of territory and posed an even greater threat to security than they had just a year previously. Yet, instead of changing tactics as units on the ground demanded, the British pulled out and handed over the Southern

\footnotetext{
2 Theo Farrell, 'Improving in War: Military Adaptation and the British in Helmand Province, Afghanistan, 2006-2009', Journal of Strategic Studies 33/4 (Aug. 2010), 567-594.
} 
Cameroons to the newly independent state of Cameroon despite the presence of a strong, active insurgency.

Archival materials suggest that this failure had political roots, highlighting a fundamental flaw in the military adaptation literature: that it ignores politics. Existing work on adaptation is overly technocratic and limited to tactical and operational considerations, thereby overlooking the crucial political imperatives, trade-offs, and opportunity costs that can impel or impede military change. Documentary evidence indicates that British politicians chose to sacrifice military effectiveness for broader strategic and political interests, thus subverting bottom-up adaptation. British leaders decided that winning on the ground in the Southern Cameroons would require delaying decolonization and committing greater numbers of combat troops, risking both their international reputation and a domestic popular backlash. This is a crucial point too often overlooked in analyses of military change. Scholars often axiomatically assume that operational efficiency is the only or most important goal during military engagements. Yet, as Clausewitz implored us to remember, war is ultimately an extension of politics. Political leaders must balance and prioritize a multitude of strategic interests, leading to decisions and outcomes that may seem counterproductive when viewed from the tactical level.

\section{Current Understandings of Military Adaptation}

The literature on military change, framed by the debate between Barry Posen and his many critics, has long privileged analyses of innovation. ${ }^{3}$ In The Sources of Military Doctrine,

\footnotetext{
${ }^{3}$ See Adam Grissom, 'The Future of Military Innovation Studies,' Journal of Strategic Studies 29/5 (Oct. 2006), 905-34.
} 
Posen argues that militaries are pathologically attached to the status quo, resisting change even when existing doctrines are clearly obsolete. Innovation thus requires civilian intervention. ${ }^{4}$ In Winning the Next War, Stephen Rosen challenges Posen's top-down framework, arguing that the specialized knowledge needed to navigate enormously complex military organizations precludes civilians from imposing change from the outside. Rather, innovation is an inside-out phenomenon that starts within the military, provided that appropriate metrics and measures, effective feedback loops, and support from high-ranking internal advocates are in place. ${ }^{5}$

This debate evolved to generate important insights on how biases, organizational culture, and bureaucratic structure foster or impede innovative behavior. Analyzing Soviet reactions to American doctrinal shifts in the Cold War, Kimberly Zisk finds that civilians and generals were equally prone to parochial interests. ${ }^{6}$ Elizabeth Kier argues that organizational culture led the interwar French and German armies to adopt very different doctrines. Although both relied on short-term conscripts for manpower, French generals were culturally predisposed to dismiss conscripts as amateurs incapable of mastering mobile warfare and thus adopted a defensive doctrine. Lacking such a constraining belief, the Germans innovated blitzkrieg warfare. ${ }^{7}$ Deborah Avant compares the U.S. and British responses to insurgency, concluding that overarching bureaucratic structure conditions innovation. While Parliament directly controlled the British

\footnotetext{
${ }^{4}$ Barry R. Posen, The Sources of Military Doctrine: France, Britain, and Germany between the World Wars (Cornell University Press 1984).

${ }^{5}$ Stephen Peter Rosen, Winning the Next War (Cornell University Press 1994).

${ }^{6}$ Kimberly Marten Zisk, Engaging the Enemy: Organization Theory and Soviet Military Innovation, 1955-1991 (Princeton University Press 1993).

${ }^{7}$ Elizabeth Kier, Imagining War: French and British Military Doctrine between the Wars (Princeton University Press 1997).
} 
Army, in the U.S., the President and Congress often fought over control. This allowed the U.S. Army to play one off the other in order to resist adopting counterinsurgency doctrine. ${ }^{8}$

While military innovation is admittedly important, adaptation is more common and, arguably, more central to waging war. ${ }^{9}$ Doctrinal innovation is a decidedly rare type of military learning - especially during war-since the pressing time constraints, overstretched resources, and multiple intelligence failures characteristic of active combat undercut the learning process at such a high bureaucratic level. ${ }^{10}$ Innovation scholars have thus tended to focus on peacetime innovation. ${ }^{11}$ Moreover, as a competitive interaction, war compels all sides to wrestle with shifts in their adversary's strategies and tactics. Fought across variegated terrain, war also necessitates repeated adjustments in tactics and technologies. Military success thus demands the constant ability to engage in incremental learning and small-scale change.

Only recently, however, have scholars turned their attention away from innovation and towards adaptation. In his 2010 article, 'Improving in War,' Farrell develops a theoretical model of bottom-up military adaptation. He argues that units are most likely to successfully adapt given that they: first, perceive pending defeat; second, possess poor organizational memory, hindering

\footnotetext{
8 Deborah D. Avant, Political Institutions and Military Change: Lessons from Peripheral Wars (Cornell University Press 1994).

${ }^{9}$ Although definitional discord exists, there is broad consensus that innovation involves 'major changes,' including doctrinal shifts or radical new weapons. In contrast, adaptation involves 'minor changes' and incremental modifications to existing practices. Emulation involves copying the 'best practices' of others. See Farrell, 'Improving in War', 569; Emily Goldman, 'Western military models in Ottoman Turkey and Meiji Japan', in Theo Farrell and Terry Terriff (eds.) The Sources of Military Change (Boulder, CO: Lynne Reinner 2002), 41-68; Williamson Murray, Military Adaptation in War: With Fear of Change (Cambridge University Press 2011).

${ }^{10}$ Rosen, Winning the Next War, $22-38$ \& $109-111$.

${ }^{11}$ Barry Posen and Elizabeth Kier restrict their analysis to interwar Europe. Kimberely Zisk studies the Cold Warera Soviet military. See also Williamson Murray and Allan Millet (eds.) Military Innovation in the Interwar Period (Cambridge University Press 1996).
} 
the retention of existing knowledge and thereby opening a broader space for new ideas; third, deploy in an organizationally decentralized manner, empowering soldiers on the ground to experiment; and, finally, exhibit high turnover in leadership, sparking change as the new leaders rotating into theatre are less wed to old practices and operating procedures. ${ }^{12}$ Farrell then evaluates his model against the British military's experience in Helmand Province. He finds that the decentralized British army, with relatively poor institutional memory, successfully adopted population-centric COIN tactics after operational failures and when new units rotated into theater.

Farrell's work represents a significant step forward in understanding military adaptation and tactical learning. Nevertheless, it has several shortcomings. Perhaps most significantly, Farrell both develops and evaluates his model within the same empirical context; neither making the case study of the British in Helmand Province a valid test of his theory nor allowing us to evaluate the model's generalizability or scope conditions.

Moreover, Farrell's conclusions within this single case study have come under dispute. In a rejoinder piece, 'Getting COIN at the Tactical Level in Afghanistan,' Catignani disputes Farrell's choice of Task Force level data as evidence of adaptation. He argues that such data reflects the experiences of relatively high-ranking officers, who have strong incentives to demonstrate the purported achievement of tactical goals. Rather, by examining the experiences of lower ranking, front line leaders, Catignani reaches the opposite conclusion: instead of shifting tactics toward influencing the allegiances of the population, as Farrell claims, British units continued to focus on enemy-centric (i.e. kinetic) operations. Thus, despite possessing the

\footnotetext{
12 Farrell, 'Improving in War,' 571-73.
} 
ideal enabling factors within Farrell's model, Catignani claims the British nonetheless failed to adapt. ${ }^{13}$

The debate over military adaption is thus severely constrained by its current limitation to a single, disputed case study, which is further confined to one Afghan province. Comparative work is necessary both to further test Farrell's model and to probe the extent of its generalizability. By exploring the model's limits in new contexts, we may also generate new theoretical insights and improvements to the model itself.

\section{Theoretical Framework: Preconditions for Adaptation}

We begin by reviewing Farrell's military adaptation model and then grounding it further within the broader organizational change and military innovation literatures. We thus generate a 'most likely' model of military adaptation that fully incorporates Farrell's insights but also includes other important, existing theoretical knowledge. In addition to three of Farrell's preconditions (decentralization, leadership turnover, and poor organizational memory), we add two additional preconditions that, according to the organizational change literature, should make successful adaptation significantly more likely: feedback loops and supportive and flexible leadership. Finally, we modify Farrell's condition of prospective defeat. Rather, following findings in the military innovation literature that suggest defeat poorly predicts change, we adopt a more modest claim: that the identification of a known and clear adversary, regardless of the prospects for victory, makes adaptation easier.

\footnotetext{
${ }^{13}$ Sergio Catignani, “"Getting COIN" at the Tactical Level in Afghanistan: Reassessing Counter-Insurgency Adaptation in the British Army', Journal of Strategic Studies 35/4 (Aug. 2012), 513-39.
} 
Decentralization: First, Farrell claims that decentralization facilitates adaptation, mirroring a key finding in the broader business and economics literatures on organizational change. Delegating authority opens increasing space for creativity and experimentation in the field. The more front line leaders experiment, the more new ideas will emerge, supporting bottom-up learning. Importantly, it matters not whether decentralization is deliberate or the result of happenstance, as is often the case in counterinsurgencies when geography undermines centralized command and control. ${ }^{14}$

Leadership Turnover: Second, both Farrell's model and general theories of organizational change argue that, within limits, higher turnover rates amongst senior commanders facilitates adaptation. ${ }^{15}$ Leadership transitions disrupt institutional memory and expose units to new approaches and practices, particularly when the leaders who rotate into theater have different backgrounds and experiences from their predecessors. Newer leaders, because they lack the same vested interest in the status quo, also tend to exhibit greater receptivity to novel ideas. ${ }^{16}$ Supportive and Flexible Leadership: There is broad consensus across disciplines that senior leaders play a decisive role in organizational learning. Indeed, scholarship on both

\footnotetext{
${ }^{14}$ Farrell, 'Improving in War', 567-94; Downie, 'Military Doctrine'; Crossan and Apaydin, 'A Multi-Dimensional Framework', 1154-91; Fariborz Damanpour, 'Organizational Innovation: A Meta-Analysis of Effects of Determinants and Moderators', The Academy of Management Journal 34/3 (Sept. 1991), 555-90; John E. Ettlie, William P. Bridges, and Robert D. O'Keefe, 'Organization Strategy and Structural Differences for Radical versus Incremental Innovation', Management Science 30/6 (June 1984), 682-95; Rowe and Boise, 'Organizational Innovation', 284-93.

${ }^{15}$ Farrell, 'Improving in War', 567-94; James G. March, 'Exploration and Exploitation in Organizational Learning', Organization Science 2/1 (Feb. 1991), 71-87; Margarethe F. Wiersema and Karen A. Bantel, 'Top Management Team Turnover as an Adaptation Mechanism: The Role of the Environment', Strategic Management Journal 14/7 (Oct. 1993), 485-504.

${ }^{16}$ Farrell, 'Improving in War', 572; Karen A. Bantel and Susan E. Jackson, 'Top Management and Innovations in Banking: Does the Composition of the Top Team Make a Difference?', Strategic Management Journal 10 (Summer 1989), 107-24.
} 
businesses and military organizations demonstrates that perhaps leaders constitute the single most important determinant of successful change. Leaders foster adaptation by creating a coherent vision and encouraging purposive action. Leaders also protect the careers of risk-taking subordinates and generate external allies and resources. Conversely, when leaders oppose change, it rarely happens. ${ }^{17}$

Poor Organizational Memory: Farrell argues that poor organizational memory facilitates adaptation in two ways. First, such poor memory decreases the ability of militaries to efficiently communicate core competencies to units, thereby engendering experimentation with new techniques since units are less thoroughly grounded in old practices. Second, poor memory may guard against the quick dismissal of novel practices. Since new ideas are especially prone to failure, and may need several rounds of modification before achieving widespread success, institutional forgetfulness permits the time and space necessary for tactical refinement. ${ }^{18}$

Feedback Loops: Rosen emphasizes that feedback loops, based in appropriate measures of effectiveness, are central to military innovation. ${ }^{19}$ As he aptly points out, no matter how

\footnotetext{
17 On business adaption, see Crossan and Apaydin, 'A Multi-Dimensional Framework', 1154-91; Damanpour, 'Organizational Innovation', 555-90; Michael D. Mumford and Brian Licuanan, 'Leading for Innovation: Conclusions, Issues, and Directions', The Leadership Quarterly 15/1 (Feb. 2004), 163-71. On military innovation and adaptation, see Rebecca Damm Patterson, 'The U.S. Army and Nation-Building: Explaining Divergence in Effective Military Innovation', PhD thesis, George Washington University, 2009; Rosen, Winning the Next War; Zisk, Engaging the Enemy.

18 Farrell, 'Improving in War', 572.

19 Rosen, Winning the Next War, 30-36 \& 179-182. Other military innovation scholars echo Rosen's insight. See Scott Gardner, Strategic Assessment in War (Yale University Press 1997), 26 - 61; Dennis Vetock, Lessons Learned: A History of US Army Lesson Learning (U.S. Army Military History Institute 1988). For a discussion of the importance of feedback to organizational learning and change in the business literature, see Stephen Kline and Nathan Rosenberg, 'An Overview of Innovation', in Ralph Landau and Nathan Rosenberg (eds.) The Positive Sum Strategy: Harnessing Technology for Economic Growth (National Academy Press 1986), 275 - 305; Bengt-Ake Lundvall, 'National Business Systems and National Systems of Innovation', International Studies of Management and Organization 29/2 (July 1999), 60-77; Mary Crossan, Henry Lane and Roderick White, 'An Organizational Learning Framework: From Intuition to Institution’, Academy of Management Review 24/3 (1999), 522-537.
} 
visionary the leader, he or she cannot foster change without recognizing its need in the first place. Leaders rely on feedback loops to continually update them on performance.

Clear Threat: Farrell argues that facing prospective defeat drives military organizations to perceive the need for change. In his view, while militaries are normally risk averse and prefer the status quo, the catastrophic costs associated with defeat spur the search for new alternatives. ${ }^{20}$ However, Farrell's argument runs counter to a compelling finding in the military change literature-that defeat poorly predicts change. ${ }^{21}$ As Rosen contends, 'history is in fact full of examples of armies and navies that were defeated and went on being defeated. ${ }^{22}$ Furthermore, defeat only enables change when leaders actually agree that the accumulated trends of battle portend overall loss. Realizing imminent loss within a counterinsurgency contest, however, is exceedingly difficult. The Koumintang's experience fighting the Chinese Communists, the French struggle against the Viet Minh, and the later American counterinsurgency against the Viet Cong, exemplify this challenge. In retrospect, all three incumbent armies lost and yet their civilian and military leaders routinely and often fundamentally disagreed about whether they were, in fact, wining or losing.

While these empirical and theoretical reasons lead us to question the link between defeat and adaptation, a more modest claim is nevertheless possible. Scholars have shown that

\footnotetext{
${ }^{20}$ Farrell, 'Improving in War', 571.

${ }^{21}$ In fact, in making the case for 'fear of defeat,' Farrell cites research based on cases of peacetime change. Ibid, footnote 20 .

${ }^{22}$ Rosen, Winning the Next War, 9.
} 
organizational learning becomes easier as threats and adversaries grow clearer. ${ }^{23}$ This claim is probabilistic, not deterministic. New threats or adversaries may sometimes fail to trigger corresponding changes. Perceptions matter and failure to recognize the imperative for change--as a result of cultural predispositions, bureaucratic interests, or cognitive biases---may also facilitate organizational stagnation. ${ }^{24}$ As the threat becomes increasingly obvious, however, leaders can more easily identify organizational deficiencies and set clear objectives that, in turn, facilitate learning. ${ }^{25}$

Our best current theoretical understandings thus suggest that the joint presence of the following six preconditions creates the most likely set of circumstances for successful military adaptation: decentralization, leadership turnover, supportive leadership, poor organizational memory, feedback loops, and a clear threat.

\section{Case Study Selection: The Southern Cameroons}

We test this model of military adaptation against new case study material, drawn from British archival records on their 1960-61 counterinsurgency effort in the Southern Cameroons. This small war on the fringe of the British Empire serves as a most-likely case for successful

\footnotetext{
23 Richard Downie, "Military Doctrine and the Learning Institution: Case Studies in Low-Intensity Conflict (Ph.D. dissertation, University of Southern California 1995); Benjamin Jensen, "Military Innovation in the U.S. Army; Anarchy, Bureaucracy, and the Forging of Doctrine, 1975 - 1995 (Ph.D. dissertation, The American University 2010); MacGregor Knox and Williamson Murray, The Dynamics of Military Revolution, 1300-2050 (Cambridge University Press 2001).

24 See Graham T. Allison, Essence of Decision: Explaining the Cuban Missile Crisis, 2nd edition (New York: Longman 1999); Goldman, 'Western Military Models', 41-68; Farrell, 'Improving in War', 567-94; Kier, Imagining War, 21 - 38; Zisk, Engaging the Enemy, 11 - 30.

25 See MacGregor Knox and Williamson Murray, The Dynamics of Military Revolution, 1300-2050 (Cambridge University Press 2001).
} 
adaptation. As we will show, the British in this conflict possessed all six preconditions of the adaptation model. Moreover, not only has the British army long held a strong reputation as a learning institution, ${ }^{26}$ but it also engaged in several successful counterinsurgency campaigns following WWII and immediately preceding the conflict in Cameroon, including in both Malaya and Kenya. ${ }^{27}$ If any army should be able to adapt within a counterinsurgency context — to defeat an insurgency while politically transferring power to a stable, sovereign government — it should be the British at the close of empire.

Evaluating the adaptation model against this new case serves two purposes. First, it pushes the military adaptation literature beyond a problematic single case study design. By comparing our case to the findings of the Afghan case, and the theoretical model generated from it, we are able to create a cumulative, multi-observation research program. Through such comparison we also avoid many of the pitfalls of single case research design while preserving the contextual depth that such focus provides. ${ }^{28}$ Second, failure of the model to explain a mostlikely case (an easy test), would suggest serious limitations or flaws with existing theory while providing fertile ground for identifying alternative explanations. ${ }^{29}$

The British army in the Southern Cameroons indeed failed to adapt to a changing enemy. By the time of their departure, they had allowed the insurgent army to establish permanent bases

\footnotetext{
${ }^{26}$ See John A. Nagl, Learning to Eat Soup with a Knife: Counterinsurgency Lessons from Malaya to Vietnam (Chicago: University Of Chicago Press 2002).

27 See David French, The British Way in Counterinsurgency, 1945-1967 (Oxford University Press 2011).

${ }^{28}$ Gary King, Robert O. Keohane, Sidney Verba, Designing Social Inquiry: Scientific Inference in Qualitative Research (Princeton University Press 1994), 211-212.

${ }^{29}$ Harry Eckstein, 'Case Study and Theory in Political Science', in Fred I. Greenstein and Nelson W. Polsby (eds.) Handbook of Political Science (vol. 1): Political Science: Scope and Theory (Reading, Mass: AddisonWesley 1975), 127.
} 
and to control a large swathe of territory. The British departed at the end of 1961 with an active insurgency in place, handing an insecure territory over to the new Cameroon Republic who, with French assistance, immediately began operations. This is thus also a deviant case, enabling us to use process-tracing techniques to potentially identify where and how the model diverged from the historical case and thereby suggest theoretical refinements. ${ }^{30}$

Our findings, however, are still subject to an important scope condition: counterinsurgency operations. Counterinsurgency campaigns and conventional wars evince several fundamental differences, undermining the application of theoretical models from one context to the other. Most importantly, units conducting counterinsurgency operations must contend with a civilian population whose choices and loyalties, particularly their willingness to share information, greatly impact the course of violence. ${ }^{31}$ COIN units thus often find themselves focusing on population protection, subordinating themselves to local government institutions, limiting firepower, and accepting increased casualties in order to increase their legitimacy amongst civilians. ${ }^{32}$ The learning and adaptive process is likely to unfold quite here than in conventional war, limiting our findings to the counterinsurgency context of both our and Farrell's cases.

\footnotetext{
30 Alexander L. George and Andrew Bennett, Case Studies and Theory Development in the Social Sciences (Cambridge, Mass: MIT Press 2005), 215.

31 Stathis N. Kalyvas, The Logic of Violence in Civil War (Cambridge Univeristy Press 2006), 91-92.

32 See James F. Amos and David H. Petraeus, Counterinsurgency Field Manual FM 3-24 (University of Chicago Press 2007); Anthony James Joe, Resisting Rebellion: The History and Politics of Counterinsurgency (University Press of Kentucky 2004); Andrew Krepinevich, The Army and Vietnam (Johns Hopkins University Press 1986); Austin Long, Doctrine of Eternal Recurrence-The US Military and Counterinsurgency Doctrine, $1960-1970$ and 2003-2006 (RAND Corporation 2008); Nagl, Learning to Eat Soup with a Knife.
} 


\section{Background to the Intervention}

The insurgency in the British Southern Cameroons had its roots in neighboring French colonial policy. Following World War I, trusteeship over German Kameroun had been divided between France and Britain, who each administered their territory independently. In 1948, a political organization advocating for rapid and total independence, the Union des Populations du Cameroun (UPC) was founded in the southern part of the French territory. In the aftermath of widespread riots in 1955, France banned the UPC and barred it from participating in preindependence elections. In reaction, the UPC formed an armed wing, the Armée de Liberation Nationale Kamerun (ALNK), and soon commenced guerrilla operations. By 1960, the deteriorating security situation in French-controlled Cameroon began overflowing into the British Southern Cameroons as refugees and UPC operatives fled across the poorly guarded border. Additionally, the One Kamerun Party (OKP), founded in the British territories in 1955, sought a close relationship with the UPC and promoted unification with French Cameroon, intensifying local feelings of a growing threat. ${ }^{33}$

Initially, however, Britain was hesitant to intervene. According to the Secretary of State for the Colonies, Iain Macleod, the ministers were 'reluctant to see British troops involved in a fresh commitment whose eventual size and duration [could not] be determined.' ${ }^{34}$ Instead, they first explored alternative options such as raising a local police force or approaching Nigeria for

\footnotetext{
33 Martin Atangana, The End of French Rule in Cameroon (Lanham, Maryland: University Press of America 2010), 10-24.

${ }^{34}$ Kew, United Kingdom, The National Archives, Foreign Commonwealth Office (FCO) 141/1619 56, 'Telegraph No Personal 90 from Secretary of State for the Colonies to Governor-General, Federation of Nigeria', 22 April 1960.
} 
troops. ${ }^{35}$ When neither of these possibilities panned out, under their obligation as trustee, Britain finally agreed to dispatch an army battalion for an initial mission of nine months. ${ }^{36}$ Their operational directive was 'to assist the civil authorities in the maintenance of law, order and public morale and to act as a deterrent against terrorism and other subversive activities,' under the guidelines provided by the Queen's Regulations, the Manual of Military Law, and the War Office pamphlet, 'Keeping the Peace (Duties in Support of Civil Power)'. ${ }^{37}$ The mission thus began as one of auxiliary support to the local colonial government and police, constrained by the normal legal framework of colonial rule and without clear tactical or strategic directives. The first troops arrived on 1 August 1960 with the entire intervention force, the 1 King's Own Border Guards, being fully deployed by 21 September $1960 .{ }^{38}$

\section{Preconditions for Adaptation in the Southern Cameroons}

The British military in the Southern Cameroons exhibited all of the enabling factors that, according to existing theory, would maximize their potential to adapt in the field: they were organizationally decentralized, experienced leadership turnover, had poor organizational memory, possessed institutionalized feed back loops, were led by commanders who were supportive of operational changes, and faced a clear threat by a known adversary.

\footnotetext{
${ }^{35}$ FCO 141/1619 17-22, 'Notes on a Visit to the Southern Cameroons by P.J. Harley, Assistant Inspector General', 2 March 1960.

${ }^{36}$ FCO 141/1619 87-89, 'Letter from the Acting Governor-General of Nigeria, A.G.H. Gardner-Brown to Rt. Hon. Iain Macleod, Secretary of State for the Colonies', 8 June 1960; FCO 141/1619 176, 'Letter from Colonel B. Wilson of the War Office to Mr. C. G. Eastwood of the Colonial Office’, 20th January 1961.

${ }^{37}$ FCO 141/1619 201, 'Operational Directive for the Commanding Officer, Southern Cameroons,' 6 June 1960.

38 War Office (WO) 208/4385 61A, ‘1 King’s Own General Report', 10 July 1961.
} 
Decentralization: The British Army has a long tradition of decentralization with British field commanders granted leeway over tactics. ${ }^{39}$ In the Southern Cameroons, organizational decentralization was further accentuated by geographical unit dispersion combined with underdeveloped communication and transportation infrastructures. Companies and platoons were garrisoned in relatively isolated locations: two companies at Buea, one at Kumba, and two at Bamenda with platoons posted in the Bamenda frontier and at Mamfe and Muyuka. ${ }^{40}$ The heavily forested terrain and lack of high quality, surfaced roads made transportation difficult and although a military wireless system was installed to facilitate communication between companies, regular telephone lines only connected Buea to Kumba and Muyuka-with Mamge and Bamenda reachable by telegraph. ${ }^{41}$ These factors combined ensured that front-line commanders had great latitude in tactical command.

Leadership Turnover: One complete turnover of leadership occurred during the short British intervention. On 28 May 1961, the 1 Grenadier Guards replaced the 1 Kings Own Border Group, transferring command from Lieutenant Colonel A.W. Robinson to Lieutenant Colonel D.W. Fraser. ${ }^{42}$ This transfer occurred at the end of the original nine month deployment, opening an opportunity for a fresh leadership perspective and new ideas.

\footnotetext{
${ }^{39}$ Michael Carver, Britain's Army in the Twentieth Century (London: Macmillan in association with the Imperial War Museum 1998); Farrell, 'Improving in War', 567-94; Hew Strachan, Wellington's Legacy: The Reform of the British Army, 1830-54 (Manchester University Press 1984); John Strawson, Gentlemen in Khaki and Camouflage: The British Army, 1890-2008 (Barnsley, England: Pen \& Sword Military 2009).

40 WO 208/4385 57A, ‘Annex A to Perintrep 9/61: 1 King’s Own Border Group Intelligence Review: Southern Cameroons’, 16-28 May 1961.

${ }^{41}$ WO 208/4385 59A ‘Annex J to 1 Gren Gds Southern Cameroons Internal Security Instruction’, 29 June 1961.

42 WO 208/4386 53A, 'Perintrep 9/61', 16-28 May 1961.
} 
Supportive and Flexible Leadership: Lt. Col. Fraser held command after the aforementioned changeover in battalions, when we would expect the greatest chance of adaptation. He was an experienced counterinsurgency commander, having led troops during the Malaya Emergency in 1948 and the Cyprus Emergency in 1958. After arriving in the Southern Cameroons, he demonstrated willingness to support and implement change: immediately restructuring intelligence reports ${ }^{43}$ and commissioning an emergency contingency plan in the event of deteriorating security. ${ }^{44}$

Poor Organizational Memory: Farrell claims, in his Afghan case, that the British military has long possessed weak organizational memory, having historically done little to promulgate lessons learned, both between wars and within a conflict zone. ${ }^{45}$ In our case, despite the dissemination of after action reports and intelligence summaries (see below), no official lessons learned were developed and, beyond commanders' and soldiers' own knowledge and personal experience, no such official lessons were distributed from prior COIN campaigns. Moreover, until the 1990s, the British military assiduously avoided developing doctrine, preferring to defer flexibility to the 'man on the spot' (which also held true for colonial rule in general) ${ }^{46}$ All of which suggests that in the early 1960s there was poor institutionalization of organizational memory within the British military, creating room for the exploration of new ideas.

\footnotetext{
${ }^{43}$ WO 208/4385 56A, 'Memorandum on Perintrep (from Lt. Col. of 1 Gren Gds)', 8 June 1961.

44 WO 208/4385 59A, ‘1 Gren Gds Southern Cameroons Internal Security Instruction’, 29 June 1961.

${ }^{45}$ Farrell, 'Improving in War', 583-4.

${ }^{46}$ Huw Bennett, Fighting the Mau Mau: The British Army and Counter-Insurgency in the Kenya Emergency (Cambridge University Press 2013), 43; Farrell, 'Improving in War', 583-4; John Kiszely, 'The British Army and Approaches to Warfare since 1945', Journal of Strategic Studies 19/4 (Dec. 1996), 179-206; Colin McInnes, Hot War, Cold War: The British Army's Way in Warfare, 1945-95 (London: Brassey's 1996), 71.
} 
Feedback Loops: British forces employed a highly refined feedback loop in their fight against the ALNK. Intelligence officers in both the 1 King's Own and 1 Grenadier Guards, as well as local special branch officers, meticulously tracked a broad range of conflict metrics, including casualties (British, insurgent, and civilian), arrests, and the locations of arms caches, training camps, and leadership cells. ${ }^{47}$ They also monitored developments that defied quantification, including shifts in ALNK tactics, political and current events, and local attitudes. ${ }^{48}$ These assessments were distributed through four types of reports: periodic intelligence reports (Perintreps), after action reports (AARs), military intelligence liaison officer (MILO) reports, and turnover reports. The Perintreps were written fortnightly by the battalion intelligence section and disseminated both up the chain, to the War Office and Force Commander, and across units to the front line companies. The AARs were written by front line units after significant events and submitted up the chain, to the battalion's intelligence and operations sections. The MILO reports were written by the British intelligence officers assigned to French units and disseminated to the Force Commander as well as to the War Office. Finally, a turnover report was authored by the outgoing Force Commander for his incoming successor in advance of the replacement battalion. Key leaders carefully read and digested their Perintreps, AARs, MILOs and turnover reports. Virtually every archived copy includes formal responses, attached handwritten remarks, or comments in the margins. The critical tone found in many

\footnotetext{
${ }^{47}$ For example, see WO 208/4385 57A, Annexes A \& B to 'Perintrep 9/61: 1 King's Own Border Group Intelligence Review: Southern Cameroons', 16-28 May 1961.; WO 208/4386 69A 'Perintrep 4/61', 16 July - 4 Aug. 1961; WO 208/4386 74A, 'MILO Report No. 17', 12-26 Aug. 1961.

48 For example, see WO 208/4385 58A, 'Perintrep 1/61', 28 May - 16 June 1961; WO 208/4385 60A, 'MILO Report No. 13', June 1961; WO 208/4386 63A, 'Perintrep 2/61', 17 June - 1 July 1961.
} 
comments suggests that British officers took these reports very seriously and not as a pro forma part of their job.

These measures of tactical effectiveness allowed commanders at every level to assess gaps in performance as well as to understand the unintended effects of their combat activitiesan especially important capability in counterinsurgency. For example, after-action reports, detainee interrogations, and Perintreps showed that assaults on rebel camps rarely achieved surprise, allowing insurgents to escape into the forest through pre-planned evasion routes. ${ }^{49}$ Southern Cameroon's unguarded and porous borders presented another challenge: fleeing insurgents might leave Southern Cameroon only to re-emerge in French Cameroon, exacerbating violence there.

For instance, in Operation ALLSOPPS, Company B of 1 King's Own launched a major offensive against an insurgent encampment near the border that was initially regarded a success. Subsequent MILO reports from British intelligence officers attached to French forces, however, allowed British commanders to see that ALLSOPPS simply displaced violence across the border. ${ }^{50}$

Clear Threat: Upon arriving in country, the British Army confronted an organized and active insurgency that the French had been fighting for years. Through direct military liaisonsthe two armies exchanged Military Liaison Officers (MILOs), cultivated relationships between

\footnotetext{
49 WO 208/4385 47A, 'Report of Raid on Camp of 1st Mobile BN ALNK on April 7', 16 April 1961; WO 208/4385 48A, 'Perintrep 6/61', 1-15 Apr. 1961; WO 208/4386 50A, 'Perintrep 7/61', 16-30 Apr. 1961; WO 208/4386 67A 'Despatch No: Personal 13 from Commissioner SC to Iain Maclood, MP', 19 July 1961.

50 WO 208/4385 48A, 'Perintrep 6/61', 1-15 Apr. 1961 \& 'MILO Report No. 10', 14 April 1961.
} 
Force Commanders, and held joint monthly security meetings in alternating territories ${ }^{51}$ - the British were immediately able to gain significant information on their adversary. Intelligence documents demonstrate, moreover, a clear grasp of the ALNK, its aims, and both its capabilities and limitations. The British understood the ALNK's ideological fragmentation, its loose organizational structure, and the ability of local field commanders to evade overarching UPC control. 52

\section{Learning without Adaptation}

The British departed the Southern Cameroons on 31 September 1961, having failed to contain the growth of the ALNK, prevent the insurgents from controlling territory, or cease attacks from being launched over the border. By August of 1961, ALNK strength in the Southern Cameroons had reached 1000-1200 insurgents, mostly located in the Tombel/Mt. Koupe areathe 'red zone' - over which they had gained control..$^{53}$ Similar zones of insurgent control had been established across the border, which French and Cameroonian security forces were also unable to clear. ${ }^{54}$ Rather than fight, the rebels would slip back and forth between the territories through the dense forests, wait out attacks, and then reoccupy their various camps. ${ }^{55}$ Intelligence

\footnotetext{
51 WO 208/4386 2A, 'MILO Report No. 2', 10 Nov. 1960.

52 See, for example, WO 208/4386 80A, 'Notes on Grenadier Guards Stay in the Cameroons', 16 Oct 1961 ; WO 208/4386 70 A, 'Perintrep 5/61', 4-18 Aug. 1961.

53 WO 208/4386 69A, 'Perintrep 4/61', 16 July - 4 Aug. 1961; WO 208/4386 73A, 'Perintrep 6/61', 18 Aug. - 1 Sep. 1961.

54 WO 208/4386 73A, 'Perintrep 6/61', 18 Aug. - 1 Sep. 1961.

55 WO 208/4385 23A, 'Perintrep 3/61', 2-16 July 1961 on Operation Direction; WO 208/4386 69A, 'Perintrep 4/61', 16 July - 4 Aug. 1961 on Sasso Camp; WO 208/4386 75A, 'MILO Report No. 18', 27 Aug. - 10 Sept. 1961.
} 
reports also indicate that, in the Southern Cameroons, the ALNK had built armories and begun locally manufacturing firearms, was engaging in forced recruitment of civilians, and had established manned, defensive fortifications around their camps. ${ }^{56}$ Both France and the Cameroon Republic repeatedly appealed for increased British military operations and for a reexertion of government territorial control prior to independence. ${ }^{57}$ Yet, the British failed to accomplish either and, at unification, the Cameroon Republic had to immediately establish emergency zones in the Southern Cameroons and commence operations. ${ }^{58}$

Despite this overall failure to adapt, the documentary evidence suggests that the British were nevertheless learning. Through their intelligence collection and analysis, military commanders observed shifts in enemy tactics and strength, recognized their operational shortcomings, and identified appropriate areas for change.

The Perintreps closely tracked both the expansion of insurgent camps and the evolution of insurgent tactics. The British knew how large each insurgent unit was, who led them, where they were encamped, what types of armaments and defensive fortifications they possessed, and what types of foreign training they had received. ${ }^{59}$ From exchanges with French intelligence, they also knew that the ALNK used their bases in the British zone to launch frequent attacks

\footnotetext{
56 WO 208/4385 67A, 'Despatch No: Personal 13 from Commissioner SC to Iain Maclood, MP', 19 July $1961 . ;$ WO 208/4386 75A, 'MILO Report No. 18', 27 Aug. - 10 Sept. 1961.

57 WO 208/4385 67A, 'Despatch No: Personal 13 from Commissioner SC to Iain Maclood, MP', 19 July 1961.

58 WO 208/4386 78A, 'Perintrep 7/61', 1 - 23 Sept. 1961.

59 Especially illustrative of the accumulation of this type of knowledge are WO 208/4386 63A, 'Perintrep 2/61', 17 June - 1 July 1961; WO 208/4386 78A, Annex A to 'Perintrep No. 7/61', 1-23 Sep. 1961.
} 
across the border and that their operations against such camps had been largely ineffective. ${ }^{60}$

British intelligence officers and local commanders further identified two primary hindrances to their operational effectiveness - and communicated them to the War Office. First, they argued that insufficient translators and intelligence personnel on the front-line delayed analysis of captured documents and the interrogation of prisoners. Once insurgent leaders realized a knowledgeable member or cache of important documents had been captured, they would relocate camps. Such delays thus prevented the timely generation of actionable intelligence, undermining the battalion's ability to plan successful operations. ${ }^{61}$ Requests for additional personnel resources began as early as January of $1961 .{ }^{62}$ Second, no State of Emergency had been declared in the territory. Without the legal framework provided by Emergency law, British troops could not fire their weapons without first being fired upon. Commanders saw this as a key reason why they could not achieve surprise in raids or stop fleeing insurgents and repeatedly petitioned for the declaration of emergency. ${ }^{63}$

\section{Why No Adaptation? A Clausewitzian Twist of Fate}

If the British units in the Southern Cameroons were capable of using appropriate tactical

\footnotetext{
60 WO 208/4385 47A, 'Report of Raid on Camp of 1st Mobile BN ALNK on Apr. 7', 16 Apr. 1961; WO 208/4386 67A; WO 208/4386 69A, 'Perintrep 4/61', 16 July - 4 Aug. 1961.

61 Wo 208/4385 42A, 'Operation DO No. 7', 31 Mar. 1961; WO 208/4385 61A, ‘1 King’s Own General Report (Aug. 1, 1960 - 3 May, 1960)’, 10 July 1961.

62 WO 208/4385 9A, 'MILO Report No. 4', 20 Jan. 1961.

63 WO 208/4385 57A, 'Annex A to Perintrep 9/61: 1 King’s Own Border Group Intelligence Review: Southern Cameroons', 16-28 May 1961; WO 208/4385 61A, '1 King's Own General Report (Aug. 1, 1960 - 3 May, 1960)', 10 July 1961; WO 208/4386 52A, 'Preintrep 8/61', 1-15 May 1961; WO 208/4386 53A, 'Perintrep 9/61', 16-28 May 1961.
} 
metrics to identify their own operational shortcomings, generate ideas for solutions, and communicate these ideas to decision-makers (in the War Office when necessary), why then did they fail to adapt to changing insurgent tactics and maintain control over their territory? We argue adaptation failed because it was never implemented. And it was never implemented because the military subordinated itself to the political ends of the government. In the best Clausewitzian tradition, war operated as an extension of politics and the greater strategic interests of the retrenching British Empire trumped local military effectiveness.

In the summer of 1961 , feeling hamstrung by the current legal framework and watching the security situation deteriorate, commanders and administrators in the Southern Cameroons strongly advocated for a reconsideration of policy. First, at the end of May, in an after-action report distributed widely and to the War Office, Force Commander Lt. Col. Robinson explicitly requested a clarification of objectives:

'This whole matter does raise the question as to exactly what is the aim as regards security generally in the territory. Is it just a matter of keeping our noses clean until 1 Oct or should there be the wider aim of looking much more to the future and doing what can be done in the way of stamping out all forms of subversive activity in the short time available. For example, the 75 terrorists who escaped from the SASSO camp will live to fight another day, which they might not have been able to do if a full scale operation with all available support could have been mounted on the camp. ${ }^{64}$

Then, in July, the Southern Cameroons administration and the local military commanders, in consultation with the War Office, approached Whitehall directly to request an official review of government policy. The folio submitted to Whitehall included opinions from the Commissioner of the Southern Cameroons, the Force Commander (Lt. Col. Frasier), the Southern Cameroons

\footnotetext{
64 WO 208/4385 67A, 'Despatch No Personal 13 from Commissioner SC to Iain Maclood, MP', 19 July 1961.
} 
Joint Intelligence Committee (local military and special branch officers), and the War Office. The opinions generated by military personnel on the ground jointly advocated for increased offensive actions, a Declaration of Emergency, and a revision of the 'fire policy' in order to more effectively combat insurgent activities. ${ }^{65}$ The War Office and the local political Commissioner, however, disagreed with these on-the-ground military assessments. Rather, in their advice to the ministers, they painted a broader picture of strategy that transcended local considerations of tactical effectiveness.

The War Office outlined and discussed four possible responses to the growing insurgency: (1) do nothing prior to departure; (2) take unilateral offensive action; (3) arrange for the forces of the Cameroun Republic to immediately engage in operations; or (4) do nothing but make arrangements with Cameroun's President, Ahmadou Ahidjo, in case mass insurrection broke out in the Southern Cameroons in the waning days of the British presence.

As to the option advocated by local police and military forces, to change the legal framework and expand offensive operations, the War Office had this to say:

'We can only adopt this policy if we are prepared to reinforce the Southern Cameroons. We would then be placed in a position of principals in a repressive colonial war. Our present forces are unlikely to be able to achieve any significant success. Their action might lead to a widespread outbreak of terrorism and a situation beyond their control. Reinforcement would have to be planned. This would raise great administrative problems... and our withdrawal would almost certainly be delayed. ${ }^{66}$

The War Office thus advised political leaders that adapting tactics to regain territorial control could have negative political consequences, both for Britain's international reputation and its

$$
\begin{aligned}
& { }^{65} \text { Ibid. } \\
& { }^{66} \text { Ibid. }
\end{aligned}
$$


schedule for decolonization.

In his assessment, the Southern Cameroons Commissioner also made a strong case for inaction. Among other concerns, he warned that troop casualties might evoke a negative domestic reaction in the United Kingdom - that the public would not understand losing lives for a territory soon to be granted independence where Britain had no lingering national interest. He further argued that,

'In mounting such operations we would be doing no less than attacking Africans with white troops in an African territory two months before independence at a time when world opinion as been made brittle by events in the Congo, Angola, and elsewhere in Africa... Having regard to the condemnatory attitude adopted towards the British position over Angola and South Africa, Her Majesty's Government might find their interests further prejudiced by committing British troops to offensive action in the Southern Cameroons.' 67

Here, the Commissioner is arguing that offensive military action, particular if it is effective, would further deteriorate Britain's reputation in the region. Such a loss of reputation could have long-term political and strategic implications far more important than defeating a small insurgency in a soon to be independent colonial backwater.

This concern for Britain's broader strategic and political interests, both at home and abroad, thus comes to frame the request for change so strongly desired by front line military forces. In the end, the British government chose to halt military adaptation from below, wait out the remaining months of their colonial trusteeship, and hand over a partially insurgent-controlled and insecure territory to the Cameroon Republic. Decisions at the top-by Parliament and the War Office - thus prevented the implementation of military change.

${ }^{67}$ Ibid. 


\section{The Counterfactual Claim: What if an Emergency had been Declared?}

Of course, this argument that political imperatives blocked adaptation from below rests on the counterfactual claim that had British authorities declared an Emergency, and thereby allowed the military to pursue more aggressive counterinsurgency tactics, they would have prevailed (or at least performed better). Any such counterfactual claim over the outcome of war is difficult to establish. Insurgencies in general are highly complex and difficult to defeat. Many powerful armies have been bogged down for years conducting counterinsurgency operations and, eventually, withdrawn in defeat.

Yet, there are compelling reasons to think that, in this case, the British military would have emerged successful. First, emergency regulations legalized a extensive array of counterinsurgency and policing tactics not available otherwise, including the ability to establish free fire zones (prohibited areas), separate insurgents from the population through food control and the construction of secured villages, and criminalize and prosecute a wider variety of civilian offenses, including passive support of the rebels. ${ }^{68}$ Such tactics were used to great effect by British forces - even by the same commanders that were later deployed to Cameroon - to quash contemporary insurgencies in both Kenya and Malaya, where Emergencies were declared.

Indeed, the rebellions in these colonies were far more organized, serious threats. In contrast to the estimated 1000-1200 insurgents in the Southern Cameroons (at their peak when British forces departed), ${ }^{69}$ official estimates indicate that during the Mau Mau revolt, somewhere between

\footnotetext{
68 See David French, The British Way in Counter-Insurgency, 1945-1967 (Oxford University Press 2011), 74-104. 69 WO 208/4386 69A, 'Perintrep 4/61', 16 July - 4 Aug. 1961.
} 
$10,500-20,000$ rebels were killed or wounded. ${ }^{70}$ In the very first year of the Malaya Emergency, there were already an estimated 4,000 guerrillas; with over 12,000 communists killed, wounded, or captured by the end of the war. ${ }^{71}$ Both insurgencies were brought to heel prior to decolonization, with military operations in Kenya lasting a mere four years (1952-56).

Second, the security forces of the newly independent Cameroon Republic, with French military assistance, did break the back of the insurgency not long after the British departure. Although the last rebel leaders were not captured until 1970, the violence had all but ceased by 1962. ${ }^{72}$ If French and Cameroonian forces could quickly defeat the ALNK, then the Britishknown for their COIN effectiveness - should have been able to replicate their recent successes against much more entrenched anti-colonial rebellions here in the Southern Cameroons.

\section{Conclusion}

Ultimately, British forces failed to adapt to the insurgent threat in the Southern Cameroons. Yet, as we have argued, their failure teaches us a great deal about how, why, and when military organizations adapt. The British represented a 'best case' scenario for learning and adaptation. The British fought the ALNK, a clear adversary they understood well, in a decentralized fashion. A leadership turnover occurred when the 1 Grenadier Guards replaced the 1 King's Own in theater and archival evidence suggests that British military leaders supported change. Finally, British forces possessed an effective feedback loop linking tactical leaders to

\footnotetext{
${ }^{70}$ French, The British Way in Counter-Insurgency, 133.

${ }^{71} \mathrm{Nagl}$, Learning to Eat Soup with a Knife, 65 \& 103.

72 Harbom, Lotta Erik Melander, and Peter Wallensteen, 'Dyadic Dimensions of Armed Conflict, 1946-2007', Journal of Peace Research 45/5 (2008), 697-710.
} 
their front line subordinates, transmitting precise and relevant tactical measures of effectiveness, and filtering mountains of raw information into usable intelligence for commanders. As a result, commanders were able to effectively identify operational shortcomings.

That the British nonetheless failed to adapt is a poignant reminder that neither war nor change occur in a vacuum. Military organizations and the soldiers who lead them want to win. History suggests they are willing to be extraordinarily dynamic and flexible in their pursuit of victory. Their political masters, however, may have other plans. States - especially great powers — face multiple goals and difficult tradeoffs. In their pursuit of broader objectives, political leaders may prioritize ends and means in ways that seems counterproductive when looking at one military mission in isolation. In this case, the Southern Cameroons was one of many missions for an already over-stretched army and state. We should not be surprised that British soldiers and officers on the ground were prepared to change, but were stymied by their civilian leaders. What might seem perverse at the tactical level was quite logical when put in a broader strategic perspective.

Insofar as our theory generalizes beyond the British in the Southern Cameroons, it creates new directions for future policy and scholarly work on military adaptation. In terms of academic research, our findings suggest that adaptation should be disaggregated into its constituent phases. Each step along the path to learning exerts unique challenges on a military organization. We should not assume that the attributes and characteristics that help an organization navigate one stage will necessarily prove useful in the next. Neither recognizing failure nor identifying alternatives guarantees that adaptation will occur. By disaggregating the learning process we can discover a great deal more about how learning and adaptation unfold. 
The case also highlights an interesting dichotomy. While adaptation is a bottom-up phenomenon by definition, its most important determinant—politics-operates from the topdown. The quest to identify adaptation's organizational sources should not lead us to ignore its contextual causes and impediments. Political considerations affect adaptation by setting and changing objectives, determining and shifting metrics, allocating and reallocating resources, privileging and devaluing certain career paths, and by prescribing and proscribing acceptable options.

In terms of policy, our findings warn against placing too much faith in learning organizations. To be sure, some military organizations lack adaptation's institutional prerequisites. These forces are therefore unlikely to adapt under any circumstances. Yet, even militaries primed to adapt still require a conducive political environment. Such a lesson is apt for American policymakers, especially because the U.S. military proved so adaptive in Iraq and Afghanistan. From tapping into a literal army of academics and consultants, to facilitating blogs and discussion groups for junior officers, to disseminating lessons learned on an almost 'real time' basis via the internet and cloud computing, American servicemen and women embraced change. Such an outcome should not lull policymakers and leaders into complacency. As the British Army discovered in the Southern Cameroons, even learning organizations can fail to adapt when winning incurs a higher political cost than losing. 